\title{
Race and Alzheimer Disease Biomarkers
}

A Neglected Race

Alberto Lleó, MD, PhD, and Marc Suárez-Calvet, MD, PhD

Neurol Genet 2021;7:e574. doi:10.1212/NXG.0000000000000574

Race is a social construct with profound consequences on health. Although race does not always segregate with genetic ancestry, some genetic variants are more frequently found in certain selfidentified racial and ethnic groups. Differences in the epidemiology and the pathophysiology of Alzheimer disease $(\mathrm{AD})$ and other neurodegenerative conditions have been described in certain racial groups. Unfortunately, most studies in the field of $\mathrm{AD}$ have mainly included non-Hispanic White (NHW) participants, with an underrepresentation of other populations. In the past few years, however, research on race and ethnic differences in $\mathrm{AD}$ has grown rapidly. Some studies indicate that African Americans (AA) have a greater risk for $\mathrm{AD}$ than NHW. ${ }^{1}$ The reasons hypothesized to account for this higher risk are certain genetic risk factors associated with AA, the higher prevalence of vascular risk factors in AA, and socioeconomic factors. ${ }^{2}$ In addition, some studies have reported a different pathophysiology and pattern of $\mathrm{AD}$ biomarkers. There is evidence that AA have lower concentrations of total-Tau, phosphorylated Tau, and neurofilament light in the CSF compared with NHW. ${ }^{3}$ The differences in AD pathophysiology in racial groups can be due to various factors, such as genetic variants associated with that race, but also with other environmental factors such as socioeconomic status, diet, or medical comorbidities. Another factor that could play a role in this association is a different innate immune response to $\mathrm{AD}$ pathology.

In this issue of Neurology ${ }^{\circledR}$ Genetics, Schindler et al. ${ }^{4}$ take advantage of the racial and ethnical diversity of the Knight ADRC cohort to describe differences in soluble TREM2 (sTREM2) concentrations in the CSF in AA and NHW. AA participants had lower CSF sTREM2 concentrations, a difference that was mainly driven by the higher frequency of certain TREM2 coding variants associated with lower CSF sTREM2. These results remained significant after adjusting by age, sex, education, history of dementia, and APOE 4 status. The authors also confirmed their findings in participants of the ADNI cohort.

TREM2 is an innate immune receptor of the immunoglobulin family that is expressed on the plasma membrane of microglia and other myeloid lineage cells. TREM2 is involved in microglia migration, proliferation, phagocytosis, and lipid sensing. ${ }^{5}$ Low frequency coding variants in TREM2 increase the risk of $A D .{ }^{5}$ In mouse models of $A D$, impaired TREM2 function limits the microglia response around Amyloid- $\beta(\mathrm{A} \beta)$ plaques and leads to greater neuritic dystrophy. ${ }^{5}$ These observations are consistent with a model in which defective TREM2 function affects microglial response to $\mathrm{A} \beta$ plaques and increases neuronal and synaptic damage.

CSF sTREM2 reflects the amount of TREM2 competent signaling on the surface of microglia and can thus be used as a biomarker of the TREM2-mediated microglia response. CSF sTREM2 dynamically changes throughout the Alzheimer continuum, with higher levels in the later asymptomatic stages and early symptomatic stages of both sporadic and autosomal-dominant $\mathrm{AD}{ }^{6,7}$ It is important that lower CSF sTREM2 concentrations have been associated with faster cognitive decline in patients with $\mathrm{AD},{ }^{8}$ which supports the notion that sTREM 2 can be used as a

\begin{abstract}
Correspondence
Dr. Lleó

alleo@santpau.cat
\end{abstract}

\section{RELATED ARTICLE}

African Americans Have Differences in CSF Soluble TREM2 and Associated Genetic Variants

Page e571 
surrogate marker of microglial activity in $\mathrm{AD}$. This observation also suggests that TREM2-mediated microglial response may have a beneficial effect in $\mathrm{AD}$, at least at some disease stages.

The work of Schindler et al. has important clinical implications. First, if AA have lower CSF TREM2 concentrations, the question arises of whether AA may be less protected by TREM2related microglial function. Second, if $A A$ show different $A D$ biomarkers, it is important to account for race when designing cutoffs in a diverse population. Third, because TREM2 is expressed in other tissue macrophages, TREM2 coding variants associated with AA may also induce a different peripheral inflammatory response. The peripheral inflammatory response is known to influence cognitive disorders and progression of $\mathrm{AD},{ }^{9}$ which could also have an impact on $\mathrm{AD}$ pathophysiology.

Finally, the findings reported by Schindler et al. may have therapeutic implications. Therapies that target TREM2 have already reached clinical phase 2 (NCT04592874). There is an ongoing clinical trial with a TREM2 activating antibody that enhances the protective functions of microglia in a mouse model of $\mathrm{AD} .^{10}$ It will be important to investigate whether TREM2 therapies have a different effect in participants with lower TREM2 function, irrespective of self-identified race. If true, then it would be key to monitor TREM2 function and adjust the dose accordingly. This would require the development of accurate assays to monitor microglial function through the course of the disease.

In summary, the study by Schindler et al., adds on an important and under-investigated aspect of $\mathrm{AD}$. Because clinical trials grow and enroll patients with different races and ethnicities, it will be important to take both into account when interpreting outcomes.

\section{Study Funding}

The authors report no targeted funding.

\section{Disclosure}

A. Lleó has served as a consultant or at advisory boards for Fujirebio-Europe, Roche Diagnostics, Biogen, and Nutricia. In addition, A. Lleó has a patent WO2019175379 A1 Markers of synaptopathy in neurodegenerative disease issued. $M$. Suárez-Calvet has served as a consultant and at advisory boards for Roche Diagnostics International Ltd and has given lectures in symposia sponsored by Roche Diagnostics. Go to Neurology.org/NG for full disclosures.

\section{References}

1. Mayeda ER, Glymour MM, Quesenberry CP, Whitmer RA. Inequalities in dementia incidence between six racial and ethnic groups over 14 years. Alzheimers Dement 2016;12:216-224.

2. Howard G, Safford MM, Moy CS, et al. Racial differences in the incidence of cardiovascular risk factors in older black and white adults. J Am Geriatr Soc 2017;65: 83-90.

3. Howell JC, Watts KD, Parker MW, et al. Race modifies the relationship between cognition and Alzheimer's disease cerebrospinal fluid biomarkers. Alzheimers Res Ther 2017;9:88.

4. Schindler SE, Cruchaga C, Joseph A, et al. African Americans have differences in CSF soluble TREM2 and associated genetic variants. Neurol Genet 2021;7:e571. doi: 10 . 1212/NXG.0000000000000571.

5. Ulland TK, Colonna M. TREM2: a key player in microglial biology and Alzheimer disease. Nat Rev Neurol 2018;14:667-675.

6. Suarez-Calvet M, Kleinberger G, Araque Caballero MA, et al. sTREM2 cerebrospinal fluid levels are a potential biomarker for microglia activity in early-stage Alzheimer's disease and associate with neuronal injury markers. EMBO Mol Med 2016;8: 466-476.

7. Suárez-Calvet M, Araque Caballero MÁ, Kleinberger G, et al. Early changes in CSF sTREM2 in dominantly inherited Alzheimer's disease occur after amyloid deposition and neuronal injury. Sci Transl Med 2016;8:369ra178.

8. Ewers M, Franzmeier N, Suarez-Calvet $M$, et al. Increased soluble TREM2 in cerebrospinal fluid is associated with reduced cognitive and clinical decline in Alzheimer's disease. Sci Transl Med 2019;11:eaav6221.

9. Holmes C, Cunningham C, Zotpleaseova E, et al. Systemic inflammation and disease progression in Alzheimer disease. Neurology 2009;73:768-774.

10. Wang S, Mustafa M, Yuede CM, et al. Anti-human TREM2 induces microglia proliferation and reduces pathology in an Alzheimer's disease model. J Exp Med 2020; 217:e20200785. 


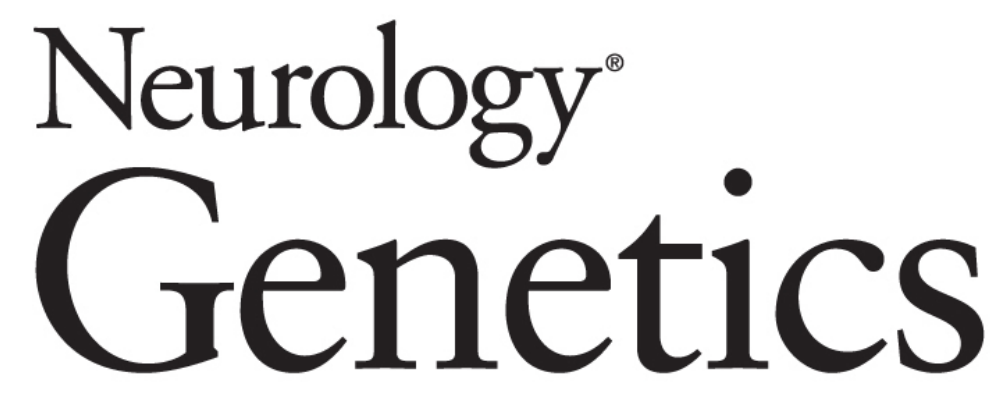

\section{Race and Alzheimer Disease Biomarkers: A Neglected Race \\ Alberto Lleó and Marc Suárez-Calvet \\ Neurol Genet 2021;7; \\ DOI 10.1212/NXG.0000000000000574}

This information is current as of March 4, 2021

\section{Updated Information \& Services}

References

Subspecialty Collections

Permissions \& Licensing

Reprints including high resolution figures, can be found at: http://ng.neurology.org/content/7/2/e574.full.html

This article cites 10 articles, 4 of which you can access for free at: http://ng.neurology.org/content/7/2/e574.full.html\#\#ref-list-1

This article, along with others on similar topics, appears in the following collection(s):

Alzheimer's disease

http://ng.neurology.org//cgi/collection/alzheimers_disease Health disparities

http://ng.neurology.org//cgi/collection/health_disparities

Information about reproducing this article in parts (figures,tables) or in its entirety can be found online at:

http://ng.neurology.org/misc/about.xhtml\#permissions

Information about ordering reprints can be found online: http://ng.neurology.org/misc/addir.xhtml\#reprintsus

Neurol Genet is an official journal of the American Academy of Neurology. Published since April 2015, it is an open-access, online-only, continuous publication journal. Copyright Copyright $\odot 2021$ The Author(s). Published by Wolters Kluwer Health, Inc. on behalf of the American Academy of Neurology.. All rights reserved. Online ISSN: 2376-7839.

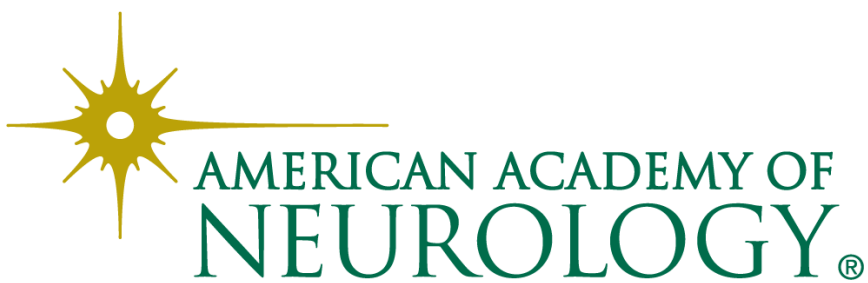

